\title{
Vietnamese Agriculture before and after Opening Economy
}

\section{Nguyen Van Song1*, Nguyen Thi Minh Phuong2\#, Ho Ngoc Cuong1, Nguyen Xuan Diep3, Do Thi Diep1, Vu Ngoc Huyen1, Vuong Thi Khanh Huyen'1, Nguyen Cong Tiep", Tran Thi Thu Trang1}

${ }^{1}$ Vietnam National University of Agriculture (VNUA), Hanoi, Vietnam

${ }^{2}$ Vinh University, Vinh, Vietnam

${ }^{3}$ Thainguyen University of Economics \& Business Administration (TNUEBA), Thainguyen, Vietnam

Email: nguyensonghua@gmail.com,nvsong@vnua.edu.vn, ${ }^{*}$ minhphuongn78@yahoo.com

How to cite this paper: Song, N. V., Phuong, N. T. M., Cuong, H. N., Diep, N. X., Diep, D. T., Huyen, V. N., Huyen, V. T. K., Tiep, N. C., \& Trang, T. T. T. (2020). Vietnamese Agriculture before and after Opening Economy. Modern Economy, 11, 894-907.

https://doi.org/10.4236/me.2020.114067

Received: February 27, 2020

Accepted: April 19, 2020

Published: April 22, 2020

Copyright ( 2020 by author(s) and Scientific Research Publishing Inc. This work is licensed under the Creative Commons Attribution International License (CC BY 4.0).

http://creativecommons.org/licenses/by/4.0/

\begin{abstract}
The output of paddy has been increased from 16.4 million tons in 1987 to 50.4 million tons in 2015, with average food per capita doubling from 275 $\mathrm{kg} /$ person (1985) to $550 \mathrm{~kg} /$ person (2015). Exports of agricultural, forestry and fishery products in 2017 reached USD 36.7 billion, an increase of 14.05\% over 2016. The main causes of this strong growth have been the economic transition from only two main business sectors in agriculture, namely state-owned farms and agricultural cooperatives to more diversify economic activity; and a shift from the centralized economy to a market economy. The most impressive leap was after the 10-NQ/TW Politburo Resolution in 1988. Resolution 10 derestricted farmers, allowing a market economy to emerge.
\end{abstract}

\section{Keywords}

Agriculture, Food, Socialism Economy, Market Economy, Resolution 10

\section{Introduction}

Vietnam's economy has seen impressive growth in recent years, especially after the transition from a centrally planned economy to a market economy. Vietnam's agriculture has also undergone impressive development since the war years of 1954-1975 and the time under a centrally planned economy.

After declaring independence on September 2, 1945, the Democratic Republic of Vietnam engaged in a nine-year war with France. The war ended in 1954 with France winning the Dien Bien Phu victory. After 1954, the Democratic Republic *First author; ${ }^{*}$ Corresponding author. 
of Vietnam started to build a socialist system. The country was divided into two regions: North and South. North Vietnam under the leadership of the Communist Party was transformed into a communist society and economy modeled according to the socialist regime, whereas South Vietnam was based on the market economy mechanism. After the Vietnam war ended in 1975, South Vietnam was reunited with North Vietnam, and the Communist regime subsequently extended its centrally planned economy to the entire country until 1987.

In 1988 Vietnam issued Resolution $10 \mathrm{NQ/TW}$ to revitalize agricultural management and meet urgent needs of agricultural development (Resolution 10 NQ/TW, 1988). The centralized, subsidized mechanism of the socialist regime was replaced by an increasing orientation towards a market economy. As a result, the economy of Vietnam, as well as Vietnamese agriculture, has made great progress. Instead of food shortages of 2 million tons each year, after only 2 years following implementation of Resolution $10 \mathrm{NQ} / \mathrm{TW}$, Vietnam exported 2 million tons of rice to the world market. Agricultural production continued to improve rapidly and continuously, at an average annual rate of $4.5 \%$, and food production increased annually by $4.8 \%$ per year (Dang, 2006).

This paper attempts to explain why the Vietnamese economy and agricultural sector have developed so rapidly after Resolution 10 and what are some of the difficulties that Vietnam is currently facing. In particular, it compares the differences between the two types of agricultural production, namely state-owned farms and collective economy, and the market-based economy in Vietnam, analyzing the basic causes of Vietnam's agricultural growth following the transition from a centralized economy to a market economy.

This paper is divided into 4 parts. The first section is an introduction to the issues that need to be researched and solved, research objectives. The second section is an explanation of the data collected and the methodology. The third section of this paper is the result of research and discussion, this section is divided and analyzed into two main parts which are before and after Vietnam promulgated Revolution 10. The final section, is the conclusion of the paper.

\section{Methodology}

\subsection{Data Collection}

The data used in this article were obtained mainly from secondary data sources including the General Statistics Office of Vietnam, the Ministry of Agriculture and Rural Development, the Ministry of Finance, the Ministry of Planning and Investment, the Institute of Agricultural Policy Research and from other relevant scientific sources.

\subsection{Data Analysis}

The main methods applied in the study were statistical analysis, comparative institutionalism analysis, systematic analysis, in-depth expert interviews, and other qualitative methods. 
Comparative institutionalism analysis shows how different forms of economic organization have been established, reproduced and changed in different market economies. It focuses on macro-level societal institutions, in particular those that govern "access to critical resources, especially labor and capital" (Whitley, 1999).

A systematic analysis of main national institutions and the interactions between these institutional arrangements and the activities of business organizations has been conceptualized in terms of "societal logic" (Maurice et al., 1986), "social systems of production" (Hollingsworth \& Boyer, 1997), "national industrial order" (Lane, 1992) or "national business systems" (Whitley, 1999).

\section{Results and Discussion}

\subsection{The Period from 1945 to 1975}

During the period from 1945 to 1975, Vietnam experienced two wars against France and America. The French war lasted nine years from 1945 to 1954, in which Vietnam was divided into South Vietnam and North Vietnam. The American war lasted for 22 years (1954-1975). The North developed the socialist economy and the South developed the market economy. In reality, the Vietnamese economy in both regions was heavily dependent on the support of foreign countries-the North by socialist countries, especially the Soviet Union, and the South receiving mainly American supports.

\subsubsection{The Period from 1945 to 1954}

In 1945, after declaring the founding of the Democratic Republic of Vietnam, the Vietnamese government under the leadership of President Ho Chi Minh immediately had to face many difficulties: French and Taiwanese troops; and more than $95 \%$ of Vietnam's population comprising farmers, illiterate with low incomes. At the same time, the budget of the young government was almost non-existent. The government introduced numerous reforms, abolishing certain types of taxes such as personal tax (per capita), property tax and reduced land tax, but these efforts were greatly impeded by resistance to the French colonialists. With a backward agricultural economy and low crop and livestock productivity, the assistance of the Soviet Union and other socialist countries for Vietnam's economy and agriculture in particular was significant.

Before the revolution of August 1945, Vietnam was feudalistic, the land was mainly allocated to landlords (Table 1), and landless farmers mainly worked for landlords. In addition, due to the policy of colonialism, most Vietnamese people were illiterate. After taking over the government, the young Vietnamese government had to face many challenges such as foreign invaders (French and Taiwanese) and problems of hunger and illiteracy.

\subsubsection{The Period from 1955-1975}

In the period 1955-1975, after the Dien Bien Phu victory, according to the Geneva Agreements Vietnam was divided into two regions. In this phase, all resources 
Table 1. Average land area per capita by social class (before 1945).

\begin{tabular}{cc}
\hline Social class & Average land area per capita $\left(\mathrm{m}^{2} /\right.$ person $)$ \\
\hline Landlords & 12,460 \\
Rich farmers & 5040 \\
Medium farmers & 1450 \\
Poor peasants & 472 \\
Laborers & 112 \\
\hline
\end{tabular}

Source: Dang Kim Son, 2006.

were directed towards the Vietnam war. North Vietnam under the socialist mechanism depended on aid from socialist countries, while South Vietnam developed its market economy mechanism with the help of the US government. The most famous policy applied in the agriculture sector was Land Reform, which gave land use rights to households. This was a breakthrough in agriculture, with extensive farmland reform stimulating rapidly growing food production. But the policy was not maintained. Instead, it was replaced by a cooperative system.

1) Land reform in North Vietnam

Land reform in the North initially opened up general economic development and agricultural activity. After the French war finished, in May 1955, the government issued eight policies to encourage the development of Vietnam's agricultural sector. The main objectives were: First, to ensure the right to use of land, and protect the private property of citizens; Second, to encourage land reclamation and tax exemption for land reclamation; Third, to have tax exemption for surplus yield and increase the productivity of farming households; Fourth, to create the freedom to hire labor, production materials and other inputs; Fifth, to encourage labor exchange between households and help for each other; Sixth, to encourage the development of sub sectors; Seventh, to protect and boost labor supply; Eighth, to protect farmer's rights. These policies initially created a mechanism similar to the market mechanism. They motivated farmers to produce and encouraged efficient use of natural and human resources.

The results of land reform are shown in Figure 1. There was an immediate increase of 2.4 tons/ha in rice production. This was an important step in transforming the economic structure of agriculture. During this time, farmers were satisfied. The policies created significant power for farmers because they changed from being landless employees to land users.

2) The period when the North had only two forms of state ownership and collective ownership

However, the vision and direction of land reform were altered quickly, replaced by a collective system in which only state-owned farms and agricultural cooperatives were allowed to exist and develop. In North Vietnam, there was a tendency to force people to enter into these two forms of activity. This policy lasted nearly 30 years. Crop and livestock productivity sharply declined during the 1960s, as well as productivity in rice. 


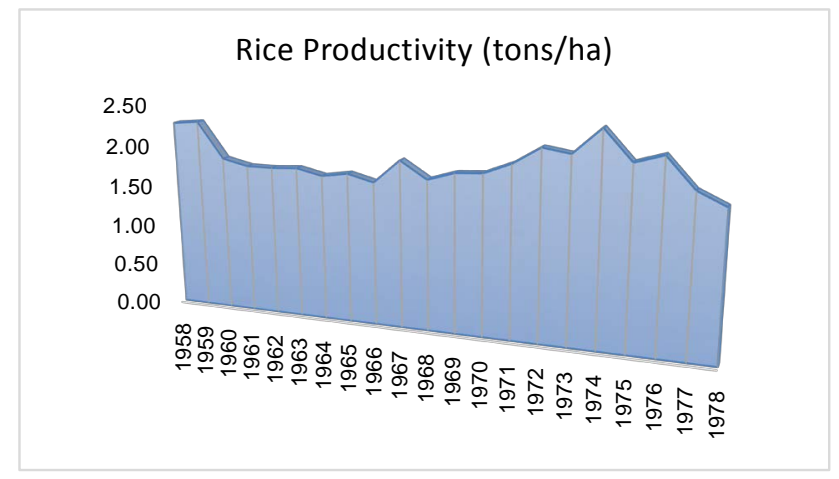

Figure 1. Rice productivity decline under state and common ownerships. Note: 1959-1975 (state and cooperative ownerships in the north of Vietnam) Since 1976 (state and cooperative ownerships in whole country). Source: Dang, 2006.

By 1960, Vietnam had completed the formation of agricultural cooperatives. The North had 40,422 agricultural cooperatives, accounting for $85 \%$ of farm households and $68 \%$ of the cultivated land and by $1975,97 \%$ of farm households took part in cooperatives (Dang, 2006).

\section{a) State-owned farm model in North Vietnam}

In the state-owned economic sector, land, labor and capital were supplied by the state to state-owned enterprises and state-owned farms. All outputs had to be handed to the government. What to produce, how to produce and for whom were decided by the government, as there was no free market during this period. Wages of workers, food and foodstuffs of workers, officials, and employees in state-owned enterprises and state-owned farms were paid by the government. Officials had the right to buy $13 \mathrm{~kg}$ of rice per month at a subsidized price, much lower than the price prevailing in illegal markets. The form of ownership together with the distribution of average benefits destroyed the motivation to work. Workers had no motivation to work hard, because regardless of their effort, they received the same wages and food each month. Their labor productivity did not determine monthly wages and food allocation. The organization of work and distribution in terms of average shares failed to encourage the creativity of managers and producers.

The production process was organized by production teams. A team leader and secretary monitored production by workers and cooperative members, including recording their participation. All jobs and operations were carried out according to the plan assigned by the government or the Ministry of Agriculture. At the beginning of each year, state-owned farms made plans for the following year. These plans covered input supply, production and product delivery. Some plans were approved after state-owned farms completed their works.

There were no market prices for inputs and outputs because the market was not accepted in this period. The government decided the price of many types of inputs and outputs. Because of price distortions, procedures for evaluating completed plans were weak. Most state-owned farms reported profitability, but over 
$90 \%$ suffered losses if input costs were properly taken into account. Since the state set a variety of input prices, there was no equilibrium market price, and although state-owned farms often reported profitability, in reality most had losses.

\section{b) Agriculture cooperative model in the North}

The second form of ownership in this phase was the ownership of land, labor and capital. Agricultural land was still owned by the state, but labor and capital were owned by agricultural cooperatives. Farmers were encouraged to join the cooperatives, which expanded markedly. Households not participating in cooperatives were considered backward or opposed to the government. The principle of volunteering and mutual benefit was not adopted in this model.

The production process in cooperatives was organized in team or groups. The captain was the person who arranged the daily work for members, allocating points for each task, while the secretary recorded each member's points in the afternoon. Under this system, farmers focused only on how many points they could get, rather than crop or livestock productivity because outputs were not directly related to them individually whereas the points were allocated by the team leader each day. At the end of the crop, the total product of cooperatives after deducting taxes, expenses of the commune, village authorities and cooperative management department was determined by dividing the remainder by the number of working days. The outcome was that in some cases farmers received only $0.2 \mathrm{~kg}$ of rice per working day. About $55 \%-65 \%$ of household income for self-employed farmers was earned from only $5 \%$ of the cultivated land, whereas $95 \%$ of the land belonging to cooperatives generated about $35 \%-45 \%$. Such was the scale of inefficiency in the use of agricultural land by cooperatives (Table 2).

Table 2. Comparison between the two forms of ownership in Vietnam agriculture.

\begin{tabular}{|c|c|c|}
\hline Criterion & State-owned farms & Agricultural cooperatives \\
\hline Ownership & $\begin{array}{l}\text { State ownership of all inputs } \\
\text { (labor, land, capital) }\end{array}$ & $\begin{array}{l}\text { State ownership of Land } \\
\text { Cooperative ownership of capital, labor }\end{array}$ \\
\hline Use right & State use right for all inputs & $\begin{array}{l}\text { Households have use right of } 5 \% \text { of } \\
\text { cultivated land; } \\
95 \% \text { of cultivated land depended } \\
\text { cooperative }\end{array}$ \\
\hline Output & $\begin{array}{l}\text { All outputs submitted to the } \\
\text { state }\end{array}$ & $\begin{array}{l}\text { Output from } 95 \% \text { of lands will be paid } \\
\text { for state taxation, commune and } \\
\text { cooperative expenditures; surplus } \\
\text { output will be divided for total } \\
\text { working days of farmers of the } \\
\text { cooperative }\end{array}$ \\
\hline Price & $\begin{array}{l}\text { No market price; Government } \\
\text { decided; many kind of input and } \\
\text { output prices }\end{array}$ & $\begin{array}{l}\text { No market price; } \\
\text { Government decided; many kind of input } \\
\text { and output prices }\end{array}$ \\
\hline Output surplus & No & Have to be sold to the government \\
\hline Salary of labor & Paid by the state & $\begin{array}{l}\text { No salary for farmers; working day paid by } \\
\text { rice }\end{array}$ \\
\hline
\end{tabular}


c) Product distribution in the socialist economy

All products made by state-owned sectors and state-owned agricultural enterprises in particular had to be handed to the state. Agricultural cooperatives had to pay taxes to the state. They sold the surplus at a price much lower than the price on the black market.

Due to lack of food, foodstuffs and active market, the government established a processing unit known as the Food and Foodstuff Department. This unit was formed to mill paddy, process pork and sell to civil servants according to the average distribution ( $13 \mathrm{~kg}$ to $17 \mathrm{~kg}$ of rice per month and 0.45 to $1 \mathrm{~kg}$ of pork/person per month) (depending on position, occupation of workers, officials at a low price, usually called the subsidized price). This mechanism was very inefficient, involving high transportation costs, and extensive corruption.

d) Consequences of economic mechanism with only two forms of ownership and distribution on average in the North of Vietnam

In this period, Vietnam's general economy and agriculture moved in opposite directions. It was a great failure and obstacle for the development of the Vietnamese economy and agricultural sector. The larger size of the cooperatives and state-owned farms made them more difficult to manage. The overall cost of production increased from $27.9 \%$ in 1964 to $48.1 \%$ in 1975 . The efficiency of farm investment declined from VND3.14 per VND invested in 1966 to just VND2.08 per VND invested in 1975. The control of district-level mechanization clearly failed (Dang, 2006).

The undesirable effects and inefficiencies of collective production were evident in low labor productivity. The productivity of crops and livestock failed to increase over the period from 1960 to 1975. Previously, in 1959, Vietnam's rice yield was the highest in Southeast Asia, but after implementation of the collective ownership mechanism, rice yield fell to the lowest in Southeast Asia of 1.8 tons/ha (Dang, 2006). The ineffectiveness of the models of collective farm and state-owned farm was evident also in the change in rice productivity over the years (Figure 1).

In the period from 1958-1959, the productivity of North Vietnam increased to over 2.0 million tons per hectare due to the influence of the land reform policy.

The model of the socialist system dominated. The more the cooperative movement expanded, the lower was the crop yield and food production. In 1975, the average yield of rice increased for the whole country, largely due to the rice yield in the south. After 1975, Vietnam applied the economic mechanism of the north in South Vietnam and Vietnam's rice and crop productivities continued to decline as the Vietnamese government applied the collective management mechanism across the whole country. The government accepted only two forms of collective and state-owned producing forms. This mechanism reduced the country's rice productivity and crop productivity in the late 1970s (Figure 1).

3) Reunification stage of the country before the renovation (1975-1987)

On April 30, 1975, the Vietnam War ended, and the country was no longer 
divided into two regions. But the opportunities for market economy development had been eradicated, and once again there was a failure of the government resulting from the application of inefficient collective machinery (centralized, bureaucratic, and subsidized) in the South. After the liberation of the South in 1975 , the country had 126,000 cooperatives engaging $65 \%$ of farmers. The involuntary participation of agricultural cooperatives resulted in inefficient use of natural and human resources, with a decisive influence on the social life of people in rural areas.

During this time, Vietnam did not accept the private economic sectors and market economy. If anybody invested and opened private companies, their capital was nationalised. Establishing private firms was illegal and violated the doctrine of socialism. This strategy created not only serious inefficiencies in the use of human and natural resource but also a serious shortfall in material goods for social needs.

The consequence of the collective, state-owned mechanism was that all the objectives of the second Five-Year Plan (1976-1980) set out by the Fourth Party Congress were not met. The Fourth Party Congress set a GDP growth rate of $13 \%-14 \%$, but in reality it was only $3.6 \%$. Industrial growth was $0.6 \% /$ year and agriculture growth was only $1.9 \%$. There was also a bad trade deficit (Le Mau, 2000). Rice production was only 13.4 million tons per year compared with the target of 21 million tons per year. Annually, Vietnam had to receive 1.6 million tons of food aid or imports. People in rural areas were greatly dissatisfied with productive performance and widespread hunger.

\subsection{Vietnam Agriculture in the Period 1988-2017}

As already mentioned, after the end of the war with the United States, Vietnam reunited the country and brought the whole country under the same socialist economic mechanism as northern Vietnam. This was a mistake, as the developing market economy in the South had to follow the economically inefficient collective economy of the North. The Vietnamese economy had almost no growth from 1975 to 1988 . The country suffered from a severe shortage of government funds. Besides the collapse of the socialist system, there was no longer support for the Vietnamese economy by socialist countries.

\subsubsection{Situation of Resolution 10 Issued, "Contract 10"}

After the unification of the country, for 13 years food production did not increase, and Vietnam continued to receive aid from socialist countries amounting to about 1.6 million tons of food each year. Although, a number of government policies addressed the shortcomings of management, production, and distribution of products, there were only two models of production. There was a lack of food, leaving people feeling discontented, with many leaving the country and migrating abroad as refugees.

In the late 1980s, aid was cut off from the major socialist countries. At the same time, in the rural area, only $5 \%$ of the agricultural land was freely allocated 
and used by farmers, but this land was so efficiently used that it was possible to increase agricultural income from $60 \%$ to $65 \%$ of total household income. Many provinces such as Vinh Phuc, Hai Phong, and Hai Duong implemented "illegal contract farming" for farmers. This process was conducted in secret, and rice yields increased dramatically. If the central government found out that this was happening, Communist Party leaders and provincial governors would be disciplined, and people's entire investment capital would be socialized.

The Sixth National Congress of the Communist Party of 1986 stated that centralized management, with only two ownership rights, does not create incentives for growth, weaken the economy, inhibit production, decreasing productivity, low product quality (The Sixth National Congress, 1986). The Congress no longer focused on investing but paid attention to the transformation of a socialist economic mechanism to a market mechanism. In the Congress, the Party and the Government of Vietnam formally accepted the existence and role of a multi-sectoral economic structure. On April 5, 1988, Resolution No. 10-NQ/TW of the Politburo (Session VI) on Renovation of Agricultural Economy Management was passed. Resolution 10 had a breakthrough effect, directly creating a leap in agricultural and rural development in Vietnam.

\subsubsection{The Basic Provisions of Resolution 10}

Resolution No. 10-NQ/TW of the Politburo (Session VI) had the following main components: Firstly, permitting land allocation for stable farm households up to 15 years; Secondly, production inputs were allocated to farmers individually; Thirdly, farmers were free to decide on cultivating their land; Fourthly, the cooperative was no longer the one who decided what to produce, how to produce, where to distribute; and cooperatives were put in charge of production or consumption of inputs and outputs. Resolution 10 created a fundamental change in the transfer of ownership from agricultural cooperatives in the collective sector to farmer households; Fifthly, outputs from production of households after paying taxes to the state, paying for services for cooperatives, products from production could be freely traded by farmers in the market; Sixthly, the exchange inputs and outputs between farmer households and service cooperatives, with other economic organization were based on the market mechanism. This mechanism introduced obligations and benefits to farmers. Farmers became independent decision-making enterprises in a market economy; the state cooperatives no longer intervened or controlled the production and distribution decisions of farmers. In addition, the government stopped consuming surplus food at a low price, implementing a one-price mechanism that has been a powerful motivator for producers to maximize profits.

Resolution 10 also introduced basic changes in the state-owned sector, especially in state-owned agricultural and forestry farms. The state abolished the pre-existing subsidy regime, renewed the management structure and allocated land to workers' families. The surplus land of state-owned farms was allocated to local authorities for the government to allocate to farmers under Resolution 10. 


\subsubsection{Rice, Food Productions of Vietnam before and after the Resolution 10}

Although implemented in 1988, Resolution 10 became very effective two years after the Government of Vietnam synchronized monetary policy, fiscal policy, removal policy, open market operations, and reform policies for state enterprises.

In combination with a number of other policies that "untied" the market, Resolution 10 helped to liberalize and promote the capacities of households and private sector. As a result, the country's annual food output leapt from 16 million (in 1987) to 19.4 million tons (in 1990), and the average food consumption per capita reached over $300 \mathrm{~kg} /$ person/year. By 1990, Vietnam had transformed itself from being an importer of more than 1 million tons of food per year to an exporter of 1.4 million tons of rice (Figure 2).

\subsubsection{Main Achievements of Vietnam's Agriculture before and after Renovation \\ 1) Rice, Food and Pig Production in Vietnam from 1985 to 2017}

The yield of paddy increased from 2.77 tons per hectare (1985) to 5.55 tons per hectare (2017), twice as much as in the years when Vietnam implemented the centralized bureaucratic mechanism. In addition to the rapid increase in crop productivity, Vietnam's annual rice production and food production increased from 16.4 million tons (1985) to 50.4 million tons (2015), a threefold increase, with an average of one million tons of food per year (Table 3 ).

2) Export of agricultural, forestry and fishery products of Vietnam in 2017

The total export value of agriculture, forestry, and fishery commodities in 2017 reached USD 36.37 billion, an increase of 13\% compared with 2016. The export value of principal agricultural products was USD 18.96 billion or 15.7\% higher over the same period, while the value of seafood exports was USD 8.32 billion, an increase of $18 \%$; The export value of main forest products was USD 7.97 billion, up 9.2\%, and in 2017 the agricultural export surplus was USD 8.55 billion (Nguyen, 2017) (Table 4).

Table 3. Rice, food, and pig production of Viet Nam in 1985-2017.

\begin{tabular}{cccccc}
\hline Year & $\begin{array}{c}\text { Rice productivity } \\
\text { (tons/ha) }\end{array}$ & $\begin{array}{c}\text { Rice production } \\
(1000 \text { tons })\end{array}$ & $\begin{array}{c}\text { Food production } \\
\text { (1000 tons) }\end{array}$ & $\begin{array}{c}\text { Food } \\
\text { (kg/person/ year) }\end{array}$ & $\begin{array}{c}\text { Pig production } \\
(1000 \text { tons })\end{array}$ \\
\hline 1985 & 2.77 & $15,859.0$ & $16,446.3$ & 274.7 & No information \\
1990 & 3.11 & $19,225.1$ & $19,897.7$ & 301.4 & No information \\
1995 & 3.77 & $24,963.7$ & $26,142.5$ & 363.1 & No information \\
2000 & 4.29 & $32,529.5$ & $34,538.9$ & 444.9 & 1418.1 \\
2005 & 4.89 & $35,832.9$ & $39,621.6$ & 480.9 & 2288.3 \\
2010 & 5.54 & $40,005.6$ & $44,632.2$ & 513.4 & 3036.4 \\
2015 & 5.60 & $45,105.5$ & $50,394.3$ & 549.5 & 3491.6 \\
2016 & 5.55 & $43,609.5$ & $48,838.9$ & 526.9 & 3664.6 \\
2017 & 5.55 & $42,839.0$ & $47,974.5$ & 517.6 & 3700.0 \\
\hline
\end{tabular}

Source: Vietnam Annual Statisitics Yearbooks (1985-2017). 
Table 4. Export value of agricultural, forestry and fishery products of Vietnam in 2017.

\begin{tabular}{cccc}
\hline \multirow{2}{*}{ Criteria } & \multicolumn{2}{c}{ Year } & Comparison \\
\cline { 2 - 4 } & 2016 & 2017 & $2017 / 2016$ \\
& Bil. USD & Bil. USD & $\%$ \\
\hline $\begin{array}{c}\text { Total export value of agriculture } \\
\text { forestry and fishery }\end{array}$ & 32.18 & 36.70 & +14.05 \\
Agricultural products & 16.34 & 18.96 & +15.70 \\
Fishery products & 7.05 & 8.32 & +18.00 \\
Forest products & 7.31 & 7.97 & +9.20 \\
Other agricultural products & 1.47 & 1.45 & -1.52 \\
\hline
\end{tabular}

Source: Ministry of Agriculture and Rural Development, 2018.

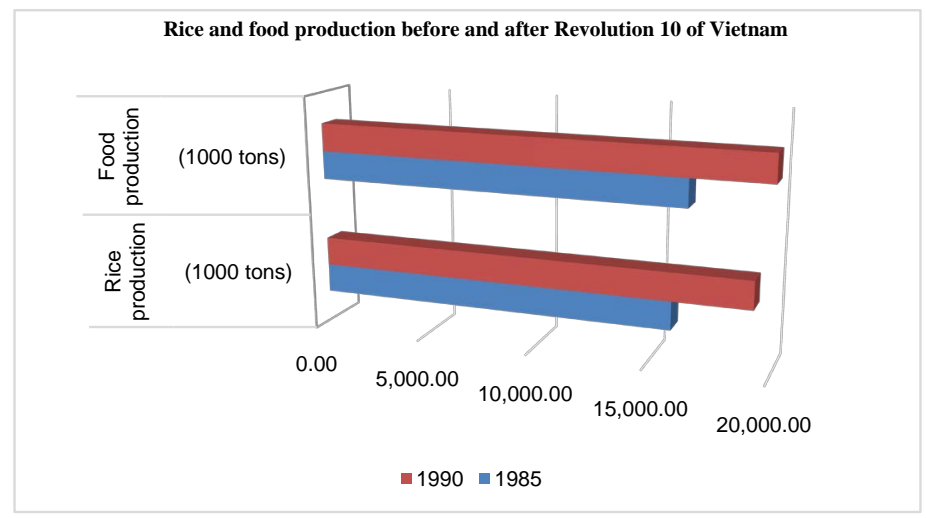

Figure 2. Comparison of rice yield and food production in Vietnam before and after giving land use rights to farmers. Assigning land use rights to farmers.

\section{3) Vietnam's agricultural contribution in the economy}

The economic structure of Vietnam has changed positively in recent years. The contribution of the agricultural sector has declined from $40 \%$ in 1990 to 15.3\% in 2017 due to rapid expansion of other sectors (Figure 3).

The share of agricultural labour as a proportion of total employment has fallen from $95 \%$ to $48 \%$ in 2017 . The quality and productivity of labor in Vietnam are both low, and these are challenges for the Vietnamese economy and agriculture sector in the coming years (Figure 4).

\subsubsection{The Development Objective of Vietnam's Agricultural Sector by 2020, with a Vision to 2030}

Based on the potential and growth rate of the agriculture, forestry and fishery sectors of Vietnam, the Government of Vietnam has developed a plan and strategy for agricultural development for the period from 2011 to 2020, as well as a vision to the year 2030. The target for GDP growth is $3 \%-4 \%$ per year, and for the value of production of agriculture, forestry and fishery, it is more than $4 \%$. Forest cover should expand from $38 \%$ of land area currently to $45 \%$ by 2020 , while the targets for export turnover are USD 40 billion by 2020, and USD 60 billion by 2030 (Table 5). 


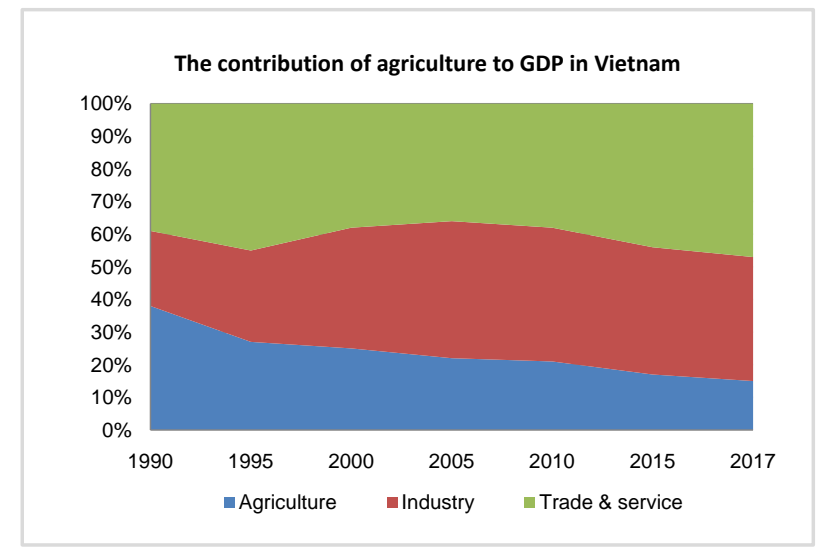

Figure 3. Vietnam's GDP structure from 1990 to 2017.

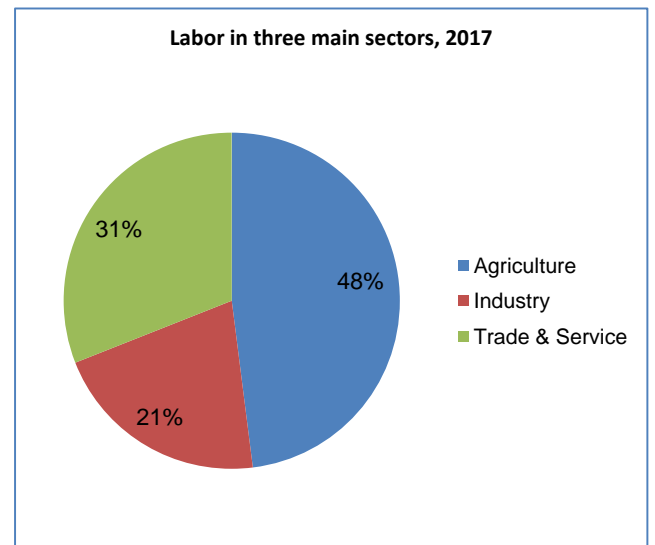

Figure 4. Labor structure of Vietnamese industries in 2017.

Table 5. Vietnam's agricultural sector by 2020, with a vision to 2030 .

\begin{tabular}{|c|c|c|}
\hline Target & The period $2011-2020$ & Vision 2030 \\
\hline GDP growth & $3.5 \%-4 \%$ & $3 \%-3.2 \%$ \\
\hline $\begin{array}{l}\text { The production value of agriculture, } \\
\text { forestry, and fisheries }\end{array}$ & $4.3 \%-4.7 \% /$ year & $4 \%-4.3 \% /$ year \\
\hline Forest cover & $44 \%-45 \%$ in 2020 & \\
\hline Export turnover & USD 40 billion & USD 60 billion \\
\hline
\end{tabular}

Source: Decision No 124/QD-TTg dated February 2, 2012.

\subsubsection{Agricultural Challenges Vietnam Has to Face in the Coming Years}

Vietnam's agriculture has seen significant growth following the Revolution 10 and broader acceptance of a market-based multi-sector economy. Over 20 years, the productivity of rice, food and pigs has tripled. However, Vietnam's agriculture still faces many difficulties and challenges in the coming years as follows:

Firstly, global climate change has had many negative impacts on traditional agriculture, especially with Vietnam being one of the ten most severely affected countries by sea level rise.

Secondly, Vietnam has joined common markets such as South East Asia and 
CPTPP and organizations such as the WTO and AFTA that will lead to high levels of competitiveness in labor, capital and product markets.

Thirdly, "Revolution 10" has "untied" the farmers, motivated them and promoted them to be decision makers. "Revolution 10 " has brought a great leap in rice and food production, but the main limitation of "Revolution 10 " is that it has resulted in fragmentation of the land, and many small plots of land creates serious diseconomies of scale. The fragmentation of land has not encouraged the application of modern technologies in the field. As a result, agricultural labor productivity is low.

Fourthly, land prices have not followed market prices. Problems of ownership and property rights have affected capital markets for farmers, especially if they seek mortgage loans.

Fifthly, there has been rapid development of industrial zones, supported by foreign investment. This is attracting strong, young labors from the agricultural sector and rural area. Therefore, rural areas and agriculture are left with old and weak laborers, in many cases, leading to abandoned agricultural lands.

\section{Conclusion}

The economic development of the socialist system in northern Vietnam lasted from the declaration of independence (1945) to the end of the Vietnam War (1975). After the unification of the country, the whole country developed under the socialist system. In this period, only two forms of production organization, namely state and collective sectors, were accepted, whilst private sector as well as market economy mechanism was unaccepted. Therefore, most resources from the private sector were not used and promoted; and the efficiencies and advantages of the market mechanism in resource allocation were also not promoted. The socialist system in the north (1945-1975) and the whole country (1975-1988) did not make either the economy or the agricultural sector successful. During those years, Vietnam lacked about 2 million tons of food annually.

Partial reforms resulted in improved economic performance, but only after the "Doi Moi" reforms (in 1986) - with an introduction of a market-based system economy-wide, had agricultural production increased significantly. The leap in the field of agriculture was witnessed after the implementation of the Resolution No. 10-NQ/TW of the Politburo. One year after the implementation of Resolution 10, from a food importing country, Vietnam became a food exporting country with nearly 2 million tons of food per year. Combining with the opening of the economy and the acceptance of the market economy mechanism, over a 30-year period (from 1988 to 2017), Vietnam's food production increased more than 3 times (from 16 million tons in 1985 to 48 million tons in 2017). The contents and ideas of the Resolution 10 are also spreading to other sectors of the economy not just agriculture. Vietnam's GDP has grown at an average of $6 \%$ in recent years.

The process of reform is continuing, and Vietnam's agriculture still faces many challenges. Since Vietnam joined the WTO, CPTPP and the Southeast 
Asian Market, there is now greater competition faced by Vietnamese industries and products. In addition, the impacts of climate change are another challenge to the country. Vietnam is among the 10 most seriously threatened countries, especially in terms of sea level rise. There is still low labour productivity and fragmented land resources across the country, while the market mechanism is not yet fully developed. These problems require further studies to propose advanced policies to overcome the difficulties facing Vietnam's agriculture.

\section{Conflicts of Interest}

The authors declare no conflicts of interest regarding the publication of this paper.

\section{References}

Dang, K. S. (2006). Rural Agriculture of Vietnam, 20 Years of Innovation and Development. Hanoi: National Political Publishing House.

Decision No. 124/QD-TTg (2012). The Prime Minister Approves the Master Plan to Develop the Agricultural Sector in 2020, with a Vision to 2030.

Hollingsworth, R. J., \& Boyer, R. (1997). Coordination of Economic Actors and Social Systems of Production. In Contemporary Capitalism the Embeddedness of Institutions. Cambridge, MA: Cambridge University Press. https://doi.org/10.1017/CBO9781139174701.001

Lane, C. (1992). European Business Systems: Britain and Germany Compared. In R. Whitley (Ed.), European Business Systems Firms and Markets in Their National Contexts. Thousand Oaks, CA: SAGE Publications.

Le Mau, H. (2000). Communist Party Congresses of Vietnam. Hanoi: National Political Publishing House.

Maurice, M., Sellier, F., \& Silvestre, J. J. (1986). The Social Foundations of Industrial Power. Cambridge, MA: MIT Press.

Ministry of Agriculture and Rural Development (2018). Conference to Summarize in 2017 and Implement the Plan in 2018. Portal of Electronic Information. https://www.mard.gov.vn/Pages/bo-nong-nghiep-va-phat-trien-nong-thon-to-chuc-ho i-nghi-tong-ket-nam-2017-va-trien-extract-aspx

Nguyen, H. (2017). Export of Agricultural, Forestry and Fishery Products in 2017 Reached 36.37 Billion USD. New Newspaper.

https://baomoi.com/xuat-khau-nong-lam-thuy-san-nam-2017-dat-36-37-ty-usd/c/2443 1443.epi

Resolution 10 NQ/TW (1988). Reforming Agricultural Economy. Vietnamese Communist Party.

The Sixth National Congress of the Communist Party of Vietnam (1986). https://en.wikipedia.org/wiki/6th_National_Congress_of_the_Communist_Party_of_V ietnam

Vietnam Annual Statisitics Yearbooks (1985-2017). Socio-Economic Data. Statistical Publisher.

Whitley, R. (1999). How and Why Are International Firms Different? The Consequences of Cross-Border Managerial Coordination for Firm Characteristics and Behavior. University of Warwick, Coventry: Presented to Sub Theme 3 "Business System in Their International Context" of the 15th EGOS Colloquium. University of Warwick. 